\section{Search for Higgs primed to start}

\section{ヒッグス粒子の探索に取りかかる準備}

Nature Vol.451(507)/ 31 January 2008

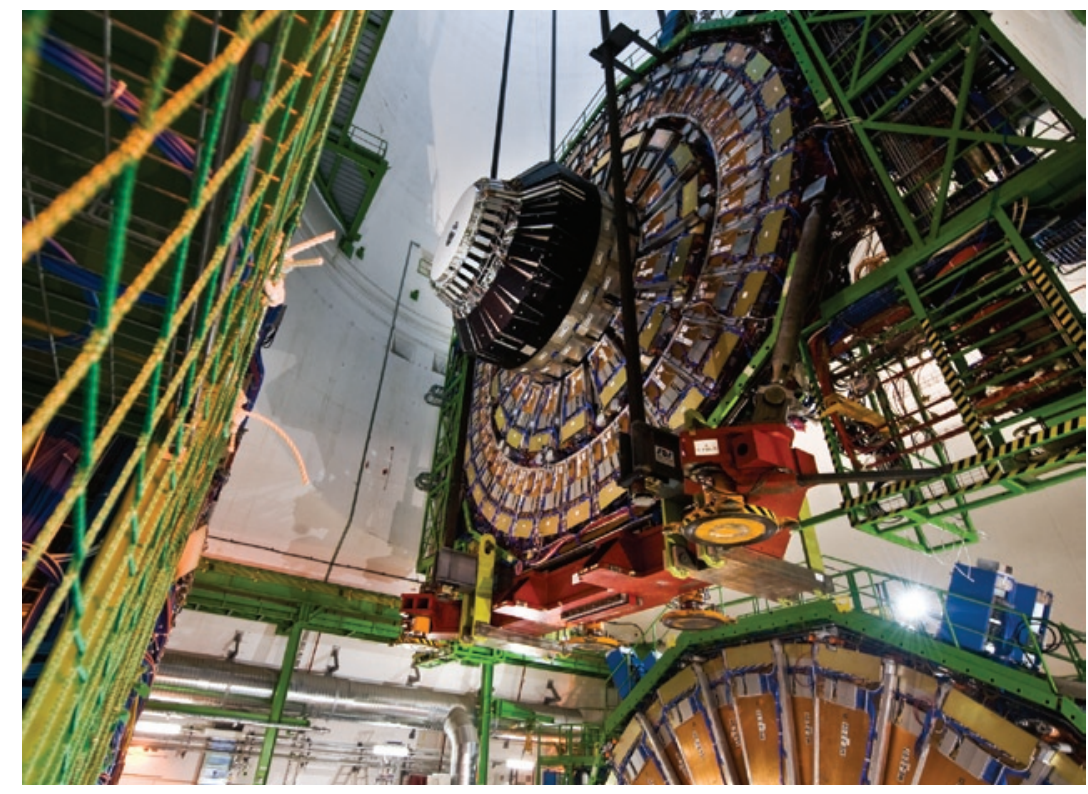

$\exists$ ヨッパの粒子物理学研究機関 CERN（スイス、ジュネーブ）で、コ ンパクトミューオンソレノイド (CMS) 検出器の最後の部品が所定の位置へ と静かに下ろされている。この検出器 は、CERNの次世代型粒子加速器「大 ハドロン衝突器」で起こるプロトンの 高エネルギー衝突の中に「標準モデ ル」を超える物理学を見つけ出そうと している。

1月22日、1430トンもある検出 器の最後の部品が、地下 100 メート ルにある空間で設置された。現地で は、研究者たちがそれをほかの 14 個の部品と組み合わせて検出器を完 成させる。CMSは、ほかのすべての 粒子に質量を与えると考えられてい る「ヒッグス粒子」の探索を導くのに 役立つと考えられている。順調であれ ば、今年の後半には最初のデータが 取れる予定である。

Geoff Brumfiel 